\title{
Estimasi Dinamika Populasi dan Pembibitan Sapi Potong di Kecamatan Bayang Kabupaten Pesisir Selatan
}

\section{Estimation of Population Dynamics and Breeding of Beef Cattle in Bayang Pesisir Selatan District}

\author{
T. Afriani*, M. P. Agusta, Yurnalis, F. Arlina, dan D. E. Putra \\ Bagian Teknologi Produksi Ternak, Fakultas Peternakan, Universitas Andalas, Padang \\ *E-mail: tindaafriani@ansci.unand.ac.id \\ (Diterima: 27 Januari 2019; Disetujui: 25 Maret 2019)
}

\begin{abstract}
ABSTRAK
Tujuan penelitian ini adalah untuk mengidentifikasi potensi sapi potong di Kecamatan Bayang Kabupaten Pesisir Selatan demi mewujudkan produksi bibit sapi potong unggul. Materi dalam penelitian ini adalah 361 orang peternak sapi potong sebagai responden. Metode yang digunakan adalah sensus dan Stratified Random Sampling. Peubah yang diukur adalah komposisi dan struktur populasi, penampilan reproduksi, natural increase (NI), net replacement rate (NRR) dan Dinamika/Estimasi populasi ternak sapi potong. Analisis data dilakukan dengan pendekatan teori pemuliabiakan ternak dan analisis time series. Hasil yang didapatkan menunjukkan komposisi ternak sapi potong di Kecamatan Bayang Kabupaten Pesisir Selatan terdiri dari sapi Pesisir (50,15\%), sapi SimPes (25,80\%), Bali (17,06\%), sapi SimPO (3,75\%), dan Brahman Cross (2,18\%). Persentase sapi potong yang keluar yaitu 6,12\%, lebih banyak dibandingkan dengan persentase ternak sapi potong yang masuk yaitu 5,10\%. Nilai natural increase (NI) ternak sapi mendapatkan presentase sebesar 17,64\% yang melihatkan pertambahan populasi sapi potong termasuk kategori sedang. Nilai net replacement rate (NRR) ternak sapi jantan $(1311,42 \%)$ dan sapi betina $(674,34 \%)$. Estimasi populasi sapi potong pada tahun 2017 sebanyak 2093,40 ekor dan tahun 2021 kekurangan sapi potong sebanyak 258,60 ekor dimana rataan terjadinya penurunan populasi pertahun sebanyak 783,92 ekor atau 25,83\%. Kesimpulan dari penelitian ini menyatakan bahwa Kecamatan Bayang Kabupaten Pesisir Selatan Provinsi Sumatera Barat dinyatakan layak untuk menjadi daerah pembibitan sapi potong.
\end{abstract}

Kata kunci: Bayang, pembibitan, potensi, produktivitas, sapi potong

\section{ABSTRACT}

The aim of this research was to determine to identify the potential of beef cattle in Bayang, Pesisir Selatan District in order to realize as breeding beef cattle center area. The material in this research was 361 breeders as respondents. The method used is census and stratified random sampling. The variables measured are composition and population structure, reproductive appearance, natural increase (NI), net replacement rate (NRR) and dynamics / estimated population of beef cattle. Data analysis was carried out using the livestock breeding theory approach and time series analysis (sequential time analysis). The results obtained showed the composition of beef cattle in the Bayang, Pesisir Selatan District consisted of Pesisir cattle (50.15\%), SimPes cattle (25.80\%), Bali cattle (17.06\%), SimPO cattle (3.75\%) and Brahman Cross cattle (2.18\%). The percentage of beef cattle that came out was $6.12 \%$, more than the percentage of incoming beef cattle which was $5.10 \%$. The natural increase value (NI) of cattle has a percentage of $17.64 \%$ which shows that the increase in the population of beef cattle is in the medium category. The net replacement rate (NRR) value of bulls (1311.42\%) and cows (674.34\%). The estimated population of beef cattle in 2017 is as much as 2093.40 tails and in 2021 there is 258.60 head of beef cattle, where the average population decline is 783.92 or $25.83 \%$. The conclusion of this research states that the Bayang, Pesisir Selatan District, was declared feasible to become a beef cattle breeding area.

Keywords: Bayang, beef cattle, breeding, potential, productivity 


\section{PENDAHULUAN}

Peternakan merupakan salah satu sub sektor dari usaha tani, dimana peternakan sangat berperan membangun perekonomian masyarakat tani khususnya. Hal ini dapat dilihat dari kesadaran masyarakat dalam memenuhi kubutuhan gizinya, terutama berasal dari produk peternakan seperti daging dan susu. Kecamatan Bayang merupakan salah satu sentra peternakan sapi di Kabuten Pesisir Selatan yang memiliki asset ternak sapi yang terdiri dari beberapa bangsa sapi lokal dan sapi-sapi hasil persilangan. Romjali et al. (2012) menyatakan bahwa ternak sapi merupakan salah satu komoditas ternak yang dapat dikembangkan di wilayahwilayah marginal di Indonesia, dan memiliki peluang serta potensi yang cukup baik untuk di kembangkan dengan model usaha yang bersifat semi intensif maupun intensif di pedesaan, selain itu juga berperan sebagai penghasil daging dan susu juga memberikan kontribusi yang tinggi bagi petani sebagai sumber tambahan penghasilan. Kecamatan Bayang diharapkan dapat dijadikan daerah sentral atau daerah pengembangan ternak sapi.

Sapi merupakan ternak ruminansia yang memiliki nilai ekonomis, selain dari memanfaatkan tenaganya untuk ternak pekerja, sapi juga dapat dijadikan sebagai usaha pokok bagi petani dan peternak. Estimasi output merupakan salah satu cara untuk melihat bagaimana pola pembiakan (breeding) suatu ternak di suatu daerah dimana output sangat dipengaruhi oleh besarnya natural increase (NI) (Hardjosubroto et al., 1990 dalam Sumadi, 2001).

Salah satu yang berkaitan dengan pembibitan adalah pengadaan bibit ternak sapi yang memiliki produktivitas tinggi, dan cara yang paling tepat adalah dengan menyeleksi ternak sapi yang memiliki mutu genetik unggul. Seleksi ternak sapi yang memiliki mutu genetik cukup baik dengan cara meningkatkan mutu genetik ternak dengan pola perkawinan yang terkontrol, pembatasan pengeluaran ternak dan perbaikan manajemen pemeliharaan ternak sehingga berpeluang memacu produktivitas dan populasi ternak sapi. Upaya untuk mengatasi keadaan tersebut maka perlu mengetahui data dasar populasi ternak sapi di Kecamatan Bayang.

\section{METODE}

\section{Materi Penelitian}

Materi yang digunakan pada penelitian ini adalah petani yang memiliki ternak sapi sebagai responden yang tersebar pada tiga kecamatan yaitu Kecamatan Linggo Sari Baganti, Kecamatan Batang Kapas dan Kecamatan IV Nagari Bayang Utara.

\section{Metode Penelitian}

Penelitian ini bersifat deskriptif analisis yang menggunakan metode survei dengan pengamatan dan pengukuran langsung terhadap sampel dan penentuan sampel menggunakan metode purpossive sampling dan quota sampling.

Peubah yang di ukur dalam penelitian ini adalah jumlah kepemilikan ternak dan komposisinya (jantan, betina, dewasa, muda dan anak), umur pertama kali dikawinkan, service per conception $(\mathrm{S} / \mathrm{C})$, batas umur pemeliharaan untuk breeding, umur sapih, lama induk dikawinkan lagi setelah beranak, umur pertama kali beranak, jarak beranak, jumlah dan jenis anak sapi yang dilahirkan pada satu tahun terkahir, mutasi ternak dan umurnya (mati, keluar dan masuk) dalam satu tahun terakhir dan interval kelahiran, cara kawin dan kondisi induk saat beranak.

\section{Analisis Data}

Data yang didapatkan dianalisis, sebagai berikut:

1. Pemilikan ternak rata-rata per responden pada waktu penelitian dilakukan yaitu jumlah populasi ternak saat survei dibagi jumlah responden.

2. Pemilikan ternak sapi potong rata-rata per responden selama setahun dihitung dengan rumus (Hardjosubroto et al., 1990) : 


$$
\begin{aligned}
\text { a. } & =\frac{P t}{R} \\
\text { b. }{ }^{P t} & =\frac{P_{a w}+P_{a k}}{2} \\
\text { c. } P_{a w} & =P_{a k}+D+G-B-E
\end{aligned}
$$

Keterangan:

$\overline{\mathrm{X}}=$ Pemilikan ternak rata-rata per peternak responden per tahun (ekor)

$\mathrm{Pt}=$ Jumlah sampel sapi potong rata-rata setahun (ekor)

$\mathrm{P}_{\mathrm{aw}}=$ Jumlah sampel sapi potong pada awal tahun atau setahun sebelum pengamatan

$\mathrm{P}_{\mathrm{ak}}=$ Jumlah sampel sapi potong pada akhir tahun (pada waktu pengamatan)

$\mathrm{D}=$ Jumlah kematian setahun

$\mathrm{G}=$ Jumlah pengeluaran ternak setahun

$\mathrm{E}=$ Jumlah pemasukan ternak selama

$\mathrm{R}=$ Jumlah peternak

d. Natural increase (NI)

Untuk mendapatkan nilai NI harus diketahui data tentang : persentase ternak sapi betina terhadap populasi, persentase kelahiran, persentase kematian (Hardjosubroto et al., 1990).

e. Persentase ternak betina terhadap populasi

- Persentase ternak betina dewasa terhadap populasi dihitung dengan cara:

$\%$ Betina Melahirkan $=\frac{\text { Jumlah Betina Melahirkar }}{\text { Jumlah Rata-Rata }}$

- Persentase ternak betina melahirkan terhadap populasi dalam satu tahun dihitung dengan cara :

$\%$ Betina Dewasa $=\frac{\text { Jumlah Betina Dewasa }}{\text { Jumlah Populasi Rata-Rata }}$

f. Persentase kelahiran adalah persentase kelahiran anak sapi dari jumlah ternak yang disurvey, dihitung dengan cara :

$\%$ Kelahiran $=$

$\frac{\text { Jumlah Kelahiran Sapi Pertahun }}{\text { Jumlah Populasi Pertahun }} x 100$

g. Persentase kematian ternak terhadap populasi dihitung dengan cara :

$\%$ Kematian $=$

$\frac{\text { Jumlah Kematian Sapi Pertahun }}{\text { Jumlah }} x 100$

Jumlah Populasi Pertahun

h. Natrural increase dihitung dengan cara:

$\mathrm{NI}=\%$ Kelahiran Pertahun - \%Kematian Pertahun

3. Ternak pengganti (replacement stock)

Merupakan perhitungan data pola pengembangbiakan ternak (lama dalam pembiakan) dan persentase kematian ternak.

\section{Nilai net replacement rate (NRR)}

Dimana jumlah ternak muda calon pengganti dibagi dengan kebutuhan ternak pengganti/tahun dikalikan $100 \%$. Jika NRR $<100 \%$ maka ternak pengganti tidak terpenuhi, sebaliknya apabila NRR $>100 \%$ maka ternak pengganti tercukupi (Sumadi et al., 2001). Populasi dihitung dengan rumus $\{(\mathrm{N}$ (awal) $+\mathrm{N}($ akhir $)) / 2\}$ Dimana populasi awal dihitung dengan rumus:

$$
\mathrm{N}(\text { awal })=\mathrm{N}(\text { akhir })+\mathrm{Di}+\mathrm{G}-\mathrm{Bi}-\mathrm{E}
$$

Keterangan:

$\mathrm{N}($ awal) $=$ jumlah populasi awal (ekor)

$\mathrm{N}=$ jumlah populasi (ekor)

$\mathrm{N}$ (akhir) = jumlah populasi akhir (ekor)

$\mathrm{Di}=$ jumlah kematian terhadap populasi setahun (ekor)

$\mathrm{G}=$ jumlah pengeluaran selama setahun (ekor)

$\mathrm{Bi}=$ jumlah kelahiran pedet terhadap populasi (ekor)

$\mathrm{E}=$ jumlah ternak yang masuk selama setahun (ekor)

5. Estimasi output

Dianalisis pada setiap populasi dengan cara dihitung berdasarkan jumlah ternak yang tersingkirkan tiap tahun dan jumlah sisa ternak pengganti. Dengan rumus:

Potensi Ternak $=$ sisa Replacement - target kenaikan populasi + ternak jantan dan betina afkir

6. Dinamika Populasi 
Menurut Supranto (1993) analisis data dinamika populasi menggunakan metode kuadrat terkecil dengan persamaan garis linear $\mathrm{Y}=\mathrm{a}+\mathrm{bX}$ :

$\mathrm{Y}=$ Data berjangka (time series data)

$\mathrm{X}=$ Waktu (tahun) $\mathrm{a}=$ Intersep, $\mathrm{b}=$ Koefisien Regresi

\section{HASIL DAN PEMBAHASAN}

\section{Komposisi dan Struktur Populasi Ternak sapi Potong}

Komposisi dan struktur populasi sapi potong dari setiap bangsa di Kecamatan Bayang Kabupaten Pesisir Selatan Provinsi Sumatera Barat tahun 2016 dapat dilihat pada Tabel 1. Komposisi ternak sapi potong di Kecamatan Bayang Kabupaten Pesisir Selatan Provinsi Sumatera Barat sebagian besar adalah sapi Pesisir (50,15\%), sapi SimPes (25,80\%), Bali (17,06\%), sapi SimPO (3,75\%), dan Brahman Cross (2,18\%). Hasil penelitian ini berbeda apabila dibandingkan dengan komposisi dan struktur poulasi hasil penelitian Putra et al. (2015) yang menyatakan di Kabupaten Pesisir Selatan sebagian besar adalah 70,78\% sapi Pesisir, 20,77\% sapi Bali, $6,05 \%$ sapi SimPO, 1,01\% SimPes, 1,20\% PO dan 0,18\% LimPO. Tingginya persentase sapi Pesisir di daerah ini karena sapi Pesisir mampu beradaptasi terhadap pakan kualitas rendah, tahan terhadap penyakit dan sistem pemeliharaan yang sederhana sehingga peternak banyak memelihara sapi Pesisir. Kemudian terdapatnya sapi SimPes, SimPO dan Brahman Cross di daerah ini, karena sapi pesisir di inseminasi buatan (IB) menggunakan semen dari pejantan sapi Simmental, sapi Peranakan Ongole dan sapi Brahman agar menghasilkan ternak unggul sehingga memiliki nilai tambah bagi peternak. Sapi Bali di datangkan dari daerah aslinya dan wilayah sebanyak Kabupaten Pesisir Selatan Sumatera Barat.

Struktur populasi berdasarkan umurnya yaitu dewasa, muda dan pedet, dengan jumlah $55,24 \%$ sapi dewasa, $26,82 \%$ muda dan $17,93 \%$ pedet. Struktur populasi sapi potong yang didapatkan dalam penelitian ini tidak sama dengan hasil penelitian Tanari et al. (2011) di Kecamatan Pamona Utara Kabupaten Poso yang memperoleh persentase sapi dewasa (70\%), sapi muda (15\%) dan sapi pedet (15\%). Hasil ini menunjukkan perbedaan dengan penelitian Putra et al. (2015) di Kabupaten Pesisir Selatan Provinsi Sumatera Barat yaitu jumlah $48,77 \%$ sapi dewasa, $24,56 \%$ muda dan $26,67 \%$ pedet. Rendahnya persentase pedet di daerah ini disebabkan karena adanya in breeding sehingga menurunkan peforma sapi dan efiensi reproduksi (ER) yang rendah. Penurunan angka kelahiran ternak dipengaruhi oleh efesiensi reproduksi dan kesuburan yang rendah akan kematian prenatal (Teolihere, 1983). Variasi kesuburan normal pada kelompok ternak akan tergantung pada faktor lingkungan sebesar $80 \%$ dan faktor genetik sebesar $20 \%$.

Dalam populasi pada penelitian ini jumlah betina dewasa relatif tinggi dan mendukung dalam program breeding oleh peternakan rakyat. Akan tetapi persentase kelahiran pedet betina relatif lebih rendah dibandingkan jumlah kelahiran pedet jantan, hal ini dapat mempengaruhi komposisi ternak sapi di daerah ini untuk beberapa tahun berikutnya. Karena daerah ini memiliki populasi ternak sapi betina yang rendah untuk dikembangbiakkan menyebabkan sedikit pedet yang lahir sehingga menurunkan populasi ternak sapi.

Direktorat Jenderal Peternakan (1998) menyatakan bahwa unit ternak (UT) sapi dewasa ( $>2$ tahun) adalah 1 , muda (1 sampai 2 tahun) adalah 0,5 dan pedet ( $<1$ tahun) adalah 0,25 . Rata-rata kepemilikan ternak sapi potong per peternak adalah 1,46 UT, artinya satu ekor dewasa dan satu ekor muda. Kepemilikan sapi per peternak pada setiap bangsa sapi adalah Pesisir sebesar 1,64 UT, Bali sebesar 1,58 UT, SimPes sebesar 1,18 UT, SimPO sebesar 1,50 UT dan Brahman Cross sebesar 1,15 UT. Hasil penelitian ini lebih rendah di bandingkan hasil penelitian Susanti et al (2015) yaitu 2,32 UT dan Putra et al (2015) 
Vol. 21 (2): 130-142

Tabel 1. Komposisi dan struktur populasi sapi potong di Kecamatan Bayang Kabupaten Pesisir tahun 2016

\begin{tabular}{|c|c|c|c|c|c|c|c|}
\hline \multirow{2}{*}{ No } & \multirow{2}{*}{ Komposisi } & \multicolumn{5}{|c|}{ Bangsa } & \multirow{2}{*}{ Jumlah total } \\
\hline & & Pesisir & Bali & SimPes & SimPO & $\mathrm{BX}$ & \\
\hline \multirow[t]{10}{*}{1} & Dewasa & & & & & & \\
\hline & Jantan (ekor) & 0,00 & 12,00 & 5,00 & 1,00 & 2,00 & 20,00 \\
\hline & (UT) & 0,00 & 12,00 & 5,00 & 1,00 & 2,00 & 20,00 \\
\hline & $(\%)$ & 0,00 & 10,26 & 2,82 & 3,03 & 13,33 & 2,92 \\
\hline & Betina (ekor) & 225,00 & 51,00 & 56,00 & 20,00 & 7,00 & 359,00 \\
\hline & (UT) & 225,00 & 51,00 & 56,00 & 20,00 & 7,00 & 359,00 \\
\hline & $(\%)$ & 65,40 & 43,59 & 31,63 & 60,60 & 46,70 & 52,33 \\
\hline & Jumlah (ekor) & 225,00 & 63,00 & 61,00 & 21,00 & 9,00 & 379,00 \\
\hline & (UT) & 225,00 & 63,00 & 61,00 & 21,00 & 9,00 & 379,00 \\
\hline & $(\%)$ & 65,41 & 53,84 & 34,46 & 63,63 & 60,00 & 55,24 \\
\hline \multirow[t]{10}{*}{2} & Muda & & & & & & \\
\hline & Jantan (ekor) & 31,00 & 15,00 & 50,00 & 4,00 & 4,00 & 104,00 \\
\hline & (UT) & 15,50 & 7,50 & 25,00 & 2,00 & 2,00 & 52,00 \\
\hline & $(\%)$ & 9,01 & 12,82 & 28,24 & 12,12 & 26,67 & 15,16 \\
\hline & Betina (ekor) & 28,00 & 14,00 & 34,00 & 3,00 & 1,00 & 80,00 \\
\hline & (UT) & 14,00 & 7,00 & 17,00 & 1,50 & 0,50 & 40,00 \\
\hline & $(\%)$ & 8,14 & 11,96 & 19,20 & 9,09 & 6,66 & 11,66 \\
\hline & Jumlah (ekor) & 59,00 & 29,00 & 84,00 & 7,00 & 5,00 & 184,00 \\
\hline & (UT) & 29,50 & 14,50 & 42,00 & 3,50 & 2,50 & 92,00 \\
\hline & $(\%)$ & 17,15 & 24,78 & 47,45 & 21,21 & 33,33 & 26,82 \\
\hline \multirow[t]{10}{*}{3} & Pedet & & & & & & \\
\hline & Jantan (ekor) & 34,00 & 10,00 & 22,00 & 3,00 & 1,00 & 70,00 \\
\hline & (UT) & 8,50 & 2,50 & 5,50 & 0,75 & 0,25 & 17,50 \\
\hline & $(\%)$ & 9,88 & 8,54 & 12,42 & 9,090 & 6,66 & 10,20 \\
\hline & Betina (ekor) & 26,00 & 15,00 & 10,00 & 2,00 & 0,00 & 53,00 \\
\hline & (UT) & 6,50 & 3,75 & 2,50 & 0,50 & 0,00 & 13,25 \\
\hline & $(\%)$ & 8,31 & 14,10 & 6,21 & 6,66 & 0,00 & 8,49 \\
\hline & Jumlah (ekor) & 60,00 & 25,00 & 32,00 & 5,00 & 1,00 & 123 \\
\hline & (UT) & 15,00 & 6,25 & 8,00 & 1,25 & 0,25 & 30,75 \\
\hline & $(\%)$ & 17,44 & 21,36 & 18,07 & 15,15 & 6,66 & 17,93 \\
\hline \multirow[t]{9}{*}{4} & Total (ekor) & 344,00 & 117,00 & 177,00 & 33,00 & 15,00 & 686,00 \\
\hline & (UT) & 269,50 & 83,75 & 111,00 & 25,75 & 11,75 & 501,75 \\
\hline & $(\%)$ & 50,15 & 17,055 & 25,80 & 3,75 & 2,18 & 100,00 \\
\hline & Jantan (ekor) & 45,00 & 37,00 & 77,00 & 8,00 & 7,00 & 174,00 \\
\hline & (UT) & 24,00 & 22,00 & 35,50 & 3,75 & 4,25 & 89,50 \\
\hline & $(\%)$ & 6,56 & 5,39 & 11,22 & 1,17 & 1,02 & 25,36 \\
\hline & Betina (ekor) & 279,00 & 80,00 & 100,00 & 25,00 & 8,00 & 492,00 \\
\hline & (UT) & 245,50 & 61,75 & 75,50 & 22,00 & 7,50 & 412,25 \\
\hline & $(\%)$ & 40,67 & 11,66 & 14,57 & 3,64 & 1,16 & 71,72 \\
\hline 5 & Total responden & 210,00 & 74,00 & 150,00 & 22,00 & 13,00 & 469,00 \\
\hline 6 & Pemilikan/responden & 1,64 & 1,58 & 1,18 & 1,50 & 1,15 & 1,46 \\
\hline
\end{tabular}

Keterangan: Pedet $=1-12$ bulan, Muda $=13-24$ bulan, Dewasa $=>24$ bulan

Pesisir $=$ sapi Pesisir, Bali $=$ sapi Bali, SimPes $=$ persilangan sapi Simmental dengan sapi Pesisir, $\operatorname{SimPO}=$ persilangan sapi persilangan Simmental dengan sapi Peranakan Ongole, BX = Brahman Cross 
Tabel 2. Penampilan reproduksi sapi potong di Kecamatan Bayang Kabupaten Pesisir Selatan tahun 2016

\begin{tabular}{|c|c|c|c|c|c|c|c|}
\hline \multirow{2}{*}{ No } & \multirow{2}{*}{ Peubah } & \multicolumn{5}{|c|}{ Bangsa (breed) } & \multirow{2}{*}{$\begin{array}{l}\text { Rata- rata } \\
\quad \pm \text { std }\end{array}$} \\
\hline & & Pesisir & Bali & SimPes & SimPO & $\mathrm{BX}$ & \\
\hline \multirow[t]{3}{*}{1.} & Umur pertama kawin & & & & & & \\
\hline & a. Jantan & 22,00 & 23,00 & 25,33 & 23,00 & 21,00 & $23,76 \pm 10,44$ \\
\hline & b. Betina & 15,18 & 19,59 & 21,45 & 21,55 & 24,00 & $17,29 \pm 3,29$ \\
\hline \multirow[t]{4}{*}{2.} & Cara kawin $(\%)$ & & & & & & \\
\hline & a. Inseminasi Buatan (IB) (AI) & 70,71 & 96,15 & 91,30 & 100,00 & 100,00 & $93,65 \pm 12,23$ \\
\hline & b. Alam & 0,00 & 0,00 & 0,00 & 0,00 & 0,00 & $0,00 \pm 0,00$ \\
\hline & c. Campuran & 29,29 & 3,84 & 8,69 & 0,00 & 0,00 & $6,34 \pm 12,23$ \\
\hline \multirow[t]{4}{*}{3.} & Pengenalan tanda berahi $(\%)$ & & & & & & \\
\hline & a. Sedang & 45,50 & 50,00 & 39,74 & 50,00 & 62,50 & $45,65 \pm 22,10$ \\
\hline & b. Baik & 43,56 & 36,66 & 51,28 & 50,00 & 25,00 & $44,02 \pm 10,81$ \\
\hline & c. Baik Sekali & 2,97 & 5,00 & 2,56 & 0,00 & 0,00 & $2,98 \pm 2,13$ \\
\hline 4. & Umur penyapihan (bulan) & 4,80 & 4,21 & 5,72 & 4,83 & 4,83 & $4,87 \pm 0,53$ \\
\hline 5. & $\begin{array}{l}\text { Umur induk pertama kali } \\
\text { beranak (bulan) }\end{array}$ & 31,53 & 35,31 & 30,42 & 32,00 & 31,25 & $31,67 \pm 1,88$ \\
\hline 6. & $\begin{array}{l}\text { Perkawinan pertama setelah } \\
\text { beranak (bulan) }\end{array}$ & 4,04 & 4,07 & 4,88 & 4,60 & 3,80 & $4,27 \pm 0,44$ \\
\hline 7. & Jarak beranak (bulan) & 1,39 & 1,98 & 2,36 & 1,80 & 2,29 & $1,66 \pm 0,39$ \\
\hline 8. & $\begin{array}{l}\text { Kondisi induk setelah } \\
\text { melahirkan }\end{array}$ & 13,45 & 13,08 & 13,08 & 13,00 & 13,80 & $13,44 \pm 0,33$ \\
\hline & a. Kurus & 42,45 & 21,87 & 30,76 & 25,00 & 25,00 & $35,23 \pm 8,17$ \\
\hline & b. Sedang & 47,16 & 62,5 & 53,84 & 66,66 & 50,00 & $52,33 \pm 8,29$ \\
\hline & c. Gemuk & 10,37 & 15,62 & 15,38 & 8,33 & 25,00 & $12,43 \pm 6,45$ \\
\hline
\end{tabular}

Keterangan: Pesisir $=$ sapi Pesisir, Bali $=$ sapi Bali, SimPes $=$ persilangan sapi Simmental dengan sapi Pesisir, SimPO = persilangan sapi persilangan Simmental dengan sapi Peranakan Ongole, BX = Brahman Cross.

yaitu 2,11 UT. Rendahnya kepemilikan ternak sapi per peternak disebabkan pemeliharaan ternak sapi hanya sebagai sambilan $(96,12 \%)$ untuk mendukung mata pencaharian utama masyarakat di daerah ini yang mayoritas petani.

\section{Penampilan Reproduksi}

Kemampuan reproduksi pada sapi potong, dapat dilihat dari penampilan reproduksi ternak tersebut Rataan sifat reproduksi sapi potong di Kecamatan Bayang Kabupaten Pesisir Selatan dapat dilihat pada Tabel 2. Dimana kemampuan petenak untuk mengenal gejalaberahimemperoleh persentase $47,10 \%$ baik/baik sekali dan 52,90\% sedang/ kurang. Pada kategori baik/baik sekali peternak mengenali kegelisahan sapi, suara sapi lebih berisik dari pada biasanya, nafsu makan berkurang dan mengenali gejala berahi dari organ reproduksi luar yang menunjukkan A-3 (abang, abuh dan anget) (Putra et al., 2015) sedangkan pada kategori sedang/ kurang peternak mengenali kegelisahan sapi, suara sapi lebih berisik daripada biasanya dan nafsu makan berkurang.

Sapi potong di Kabupaten Pesisir Selatan Provinsi Sumatera Barat 93,65\% dikawinkan secara IB dan 6,34\% kawin campuran. Hasil penelitian ini menunjukkan perbedaan dari penelitian Putra et al. (2015) yang memperoleh cara kawin ternak sapi di Kabupaten Pesisir Selatan Provinsi Sumatera 
Barat secara IB, kawin alam dan kawin ampuran secara berturut-turut mempeoleh persentase $53,39 \%, 34,63 \%$ dan $11,98 \%$. Perbedaan juga terlihat dengan hasil penelitian Susanti et al. (2015) yang memperoleh cara kawin ternak sapi di Kabupaten Banyuasin Provinsi Sumatera Selatan secara IB, kawin alam dan campuran secara berturut-turut memperoleh persentase $19,09 \%, 75,46 \%$ dan $5,44 \%$. Hal ini disebabkan karena sedikitnya ternak sapi jantan dewasa yang dipelihara untuk dijadikan pemacek. Ternak sapi jantan di daerah ini hanya digemukkan kemudian dijual untuk di potong. Dan peternak telah menerima teknologi inseminasi buatan (IB) sebagai sistem perkawinan ternak sapi menggantikan kawin alam.

Djagra dan Arka (1994) menyatakan bahwa umur pubertas sapi jantan dan betina masing-masing 20 bulan dan 17 bulan. Dijelaskan bahwa jantan telah dapat dipakai sebagai pejantan pada umur dua tahun, dan betina sebaiknya mulai dikawinkan pada umur dua tahun. Rataan umur sapi potong pertama kali kawin dilokasi penelitian yaitu sapi jantan $(23,76 \pm 10,44$ bulan) dan betina $(17,29 \pm 3,29$ bulan). Hasil penelitian yang didapatkan lebih rendah dibandingkan dengan hasil penelitian Tanari et al. (2011) dimana rataan umur pertama dikawinkan pada sapi potong adalah 30,60 bulan sapi jantan dan 28,20 bulan sapi betinan. Susanti et al. (2015) manambahkan bahwa sapi potong pertama kali dikawinkan yaitu sapi jantan $(26,21 \pm 0,47$ bulan) dan sapi betina $(23,24 \pm 0,72$ bulan), Jan et al. (2015) ternak sapi potong kawin pada umur 26,59 $\pm 3,45$ bulan pada sapi jantan dan $21,50 \pm 4,21$ bulan pada sapi betina dan Sulistia (2007) umur pertama kawin ternak sapi potong di Kabupaten Penajam Paser Utara Kalimantan Timur pada sapi jantan pada umur $26,70 \pm 0,53$ bulan. Hal ini menunjukkan bahwa dalam pembiakan ternak sapi jantan dipelihara selama 2 sampai 3 tahun. Karena ternak sapi jantan dipelihara untuk digemukkan kemudian dipotong. Ternak sapi betina dikawinkan pada saat berahi pertama kali sampai terjadi kebuntingan.
Rataan umur induk pertama kali melahirkan yang didapatkan dalam penelitian ini adalah $31,67 \pm 1,88$ bulan dan $4,27 \pm 0,44$ bulan ternak dikawinkan kembali setelah beranak. Blakely dan Bade (1991) menyatakan bahwa rata rata berahi kembali sebanyak 60 hari setelah melahirkan. Hasil penelitian ini menunjukkan bahwa induk tidak dikawinkan pada saat berahi pertama pasca beranak, karena alat reproduksi induk yang rusak setelah beranak dan keadaan pedet yang masih menyusu dan belum mampu mengkonsumsi pakan seperti sapi dewasa.

Rataan umur sapih pada sapi potong di lokasi penelitian adalah 4,83 bulan dan rataan jarak beranak adalah $13,44 \pm 0,33$ bulan. Jarak beranak dalam penelitian ini tergolong ideal, jarak beranak yang ideal adalah 365 hari (12 bulan) (Direktorat Jenderal Peternakan, 1998).

Nilai service per conception (S/C) pada penelitian ini memiliki nilai normal yaitu 1,66 . Hasil penelitian ini sama dengan hasil penelitian Murtiyeni (2011) yang mendapatkan nilai $\mathrm{S} / \mathrm{C}$ ternak sapi potong sebesar 1,60 dan hasil penelitian Putra et al. (2015) di Kabupaten Pesisir Selatan Provinsi Sumatera Barat yang mendapatkan nilai S/C sebesar 1,63, akan tetapi hasil penelitian yang didapatkan lebih tinggi di bandingkan dengan hasil penelitian Rosikh (2015) yang mendapatkan nilai $\mathrm{S} / \mathrm{C}$ ternak sapi potong sebesar 1,55 akan tetapi lebih rendah dibandingkan dengan hasil penelitian Susanti et al. (2015) di Kabupaten Banyuasin Provinsi Sumatera Selatan yaitu nilai S/C sebesar 1,88 dan hasil penelitian Tonbesi (2008) di Kabupaten Timur Tengah Utara Propinsi Nusa Tenggara Timur S/C sebesar 1,82. Nilai normal $\mathrm{S} / \mathrm{C}$ adalah 1,6 sampai 2,0. Apabila $\mathrm{S} / \mathrm{C}$ rendah, maka nilai kesuburan sapi betina semakin tinggi dan apabila nilai $\mathrm{S} / \mathrm{C}$ tinggi, maka semakin rendah tingkat kesuburan sapi-sapi betina tersebut (Affandhy et al., 2003). Hal ini menunjukkan bahwa ternak sapi betina dewasa di Kecamatan Bayang Kabupaten Pesisir Selatan Provinsi Sumatera Barat termasuk subur dan sistem perkawinan terkelola dengan baik. Menurut Nuryadi (2011) 
bahwa keberhasilan perkawinan pada induk sapi dengan adanya kebuntingan dipengaruhi oleh kesuburan betina induk, kesuburan pejantan dan tata laksana perkawinan.

Rataan kondisi induk setelah melahirkan yang didapatkan dengan katergori sedang, kurus dan gemuk secara berurutan yaitu $52,33 \%, 35,23 \%$ dan $12,43 \%$. Hal ini terjadi karena sistem pemeliharaan ektensif yang dilakukan peternak di Kecamatan Bayang Kabupaten Pesisir Selatan Provinsi Sumatera Barat. Ternak sapi di lepaskan sepanjang hari tanpa perhatian khusus dari peternak. Kondisi induk setelah melahirkan juga dipengaruhi oleh bangsa ternak sapi yang berbeda. Dimana bangsa ternak yang berbeda akan mempengaruhi konsumsi pakan karena kecepatan metabolisme pakan pada setiap ternak berbeda apabila mendapatkan pakan dengan kualitas yang sama (Sumadi et al., 1991).

Berdasarkan umur pertama kali kawin, umur induk pertama kali beranak dan jarak kelahiran maka dapat dihitung dihitung efesiensi reproduksi (ER) (Hardjosubroto, 1994) sebagai berikut:

$$
\mathrm{ER}=\frac{13,44 \times 1}{(31,67)-(17,29)+13,44-9} \times 100 \%
$$

Nilai ER yang didapatkan pada peneltian ini yaitu $71,41 \%$. Hasil penelitian ini lebih rendah dibandingkan dengan penelitian Susanti et al. (2015) yang mendapatkan nilai ER sebesar 98,27\% dan Samberi et al. (2010) yang mendapatkan nilai ER sebesar 88,38\%. Oleh sebab itu dapat disimpulkan apabila umur induk yang beranak pertama kali $>27$ bulan akan mempunyai nilai efisiensi reproduksi (ER) kurang dari $100 \%$ dan sebaliknya apabila $<27$ bulan maka nilai efisiensi reproduksi (ER) akan lebih dari 100\%. Pada penelitian ini nilai efisiensi reproduksi yang diperoleh rendah, hal ini disebabkan umur induk pertama kali beranak relatif tinggi yaitu 31,67 bulan dan juga dipengaruhi oleh jarak antara dua kelahiran yang lama yaitu 13,44 bulan. Rendahnya efisiensi reproduksi di daerah ini harus di tanggulangi dengan pembinaan inseminator dan peternak secara intensif sehingga dapat meningkatkan pengetahuan, keterampilan inseminator dan peternak.

\section{Natural Increase (NI)}

Nilai natural increase (NI) menurut Sumadi et al. (2001) didapatkan dengan cara mengurangkan tingkat kelahiran dengan tingkat kematian dalam satu wilayah tertentu dalam waktu tertentu yang biasanya diukur dalam kurun waktu satu tahun. Nilai natural increase sapi potong di Kecamatan Bayang Kabupaten Pesisir tahun 2016 dapat dilihat pada Tabel 3. Menunjukkan rataan NI pada semua bangsa sapi potong sebesar $17,64 \%$. Nilai natural increase ini lebih rendah dibandingkan dengan nilai natural increase pada penelitian Putra et al. (2015) yaitu sebesar $29,46 \%$, Sulistia (2007) sebesar $22,02 \%$, Susanti et al. (2015) sebesar 24,39\%. Lebih tinggi dari hasil penelitian Tanari et al. (2011) yaitu sebesar 12,13\% dan Makanuwey (2009) sebesar 15,92\%.

Persentase nilai NI/bangsa sapi potong yang didapatkan dalam penelitian ini yaitu sapi Pesisir sebesar 16,86\%, sapi Bali sebesar $21,37 \%$, sapi SimPes sebesar 18,08\%, sapi SimPO sebesar $15,15 \%$ dan sapi Brahman Cross sebesar $6,67 \%$. Nilai NI sapi Bali pada penelitian ini lebih tinggi dibandingkan penelitian Samberi et al. (2010) yaitu sebesar $18,18 \%$. Sapi Bali pada penelitian ini mempunyai nilai NI yang relatif tinggi dari pada sapi Pesisir, sapi SimPO, sapi SimPes dan sapi Brahman Cross. Hal ini terjadi karena tingkat kelahiran sapi Bali terhadap populasi lebih tinggi yaitu $21,55 \%$ dibandingkan sapi SimPes sebesar 18,08\%, Pesisir sebesar 17,44\%, SimPO sebesar 15,15\% dan Brahman Cross sebesar $6,67 \%$. Yang menyebabkan nilai NI sapi Bali tinggi dibandingkan bangsa lainnya di daerah ini karena tidak adanya sapi Bali yang mati. Karena daya adaptasi sapi Bali yang baik, tahan terhadap penyakit dan dapat mengkonsumsi pakan yang berkualitas rendah.

Rentang nilai NI antara $0,00-45,90 \%$, rentang dimana nilai NI digolongkan menjadi 
Tabel 3. Natural increase sapi potong di Kecamatan Bayang Kabupaten Pesisir Selatan tahun 2016

\begin{tabular}{|c|c|c|c|c|c|c|c|}
\hline \multirow{2}{*}{ No } & \multirow{2}{*}{ Peubah } & \multicolumn{5}{|c|}{ Bangsa (breed) } & \multirow{2}{*}{$\begin{array}{l}\text { Semua } \\
\text { Bangsa }\end{array}$} \\
\hline & & Pesisir & Bali & SimPes & SimPO & $\mathrm{BX}$ & \\
\hline 1 & Populasi & 344,00 & 117,00 & 177,00 & 33,00 & 15,00 & 684 \\
\hline 2 & Populasi induk (ekor) & 225,00 & 51,00 & 55,00 & 20,00 & 7,00 & 358 \\
\hline 3 & $\begin{array}{l}\text { Populasi induk terhadap } \\
\text { populasi }(\%)\end{array}$ & 65,41 & 43,97 & 30,07 & 60,61 & 46,67 & 52,34 \\
\hline \multirow[t]{7}{*}{4} & Kelahiran (ekor) & 60,00 & 25,00 & 32,00 & 5,00 & 1,00 & 123,00 \\
\hline & a. Jantan (ekor) & 34,00 & 10,00 & 22,00 & 3,00 & 1,00 & 70,00 \\
\hline & Terhadap induk (\%) & 15,11 & 19,61 & 40,00 & 15,00 & 14,29 & 19,55 \\
\hline & Terhadap populasi (\%) & 10,83 & 8,62 & 10,63 & 9,09 & 6,67 & 10,20 \\
\hline & b. Betina (ekor) & 26,00 & 15,00 & 10,00 & 2,00 & 0,00 & 53,00 \\
\hline & Terhadap induk (\%) & 11,56 & 29,41 & 18,18 & 10,00 & 0,00 & 14,80 \\
\hline & Terhadap populasi (\%) & 7,56 & 12,93 & 5,56 & 6,06 & 0,00 & 7,73 \\
\hline \multirow[t]{3}{*}{5} & Tingkat kelahiran & & & & & & \\
\hline & a. Terhadap induk (\%) & 26,67 & 49,02 & 58,18 & 25,00 & 14,29 & 34,36 \\
\hline & b. Terhadap populasi (\%) & 17,44 & 21,37 & 18,08 & 15,15 & 6,67 & 17,93 \\
\hline \multirow[t]{3}{*}{6} & Kematian ternak terhadap & pulasi & & & & & \\
\hline & a. Ekor (head) & 2,00 & 0,00 & 0,00 & 0,00 & 0,00 & 2,00 \\
\hline & b. Terhadap populasi (\%) & 0,58 & 0,00 & 0,00 & 0,00 & 0,00 & 0,29 \\
\hline 7 & Natural increase (NI) (\%) & 16,86 & 21,37 & 18,08 & 15,15 & 6,67 & 17,64 \\
\hline
\end{tabular}

Keterangan: Pesisir $=$ sapi Pesisir, Bali $=$ sapi Bali, SimPes $=$ persilangan sapi Simmental dengan sapi Pesisir, SimPO = persilangan sapi persilangan Simmental dengan sapi Peranakan Ongole, BX = Brahman Cross.

tiga kategori yaitu jika nilai NI 0,00-15,00\% termasuk kategori rendah, $15,01-30,00 \%$ termasuk kategori sedang dan 30,01-45,90\% termasuk kategori tinggi. Hasil penelitian menunjukan bahwa nilai NI sapi Pesisir, sapi Bali, SimPes, SimPO tergolong sedang, sedangkan nilai NI pada Brahman Cross tergolong rendah. Nilai NI pada Brahman Cross tergolong rendah karena persentase induk terhadap total populasi rendah yaitu $1,02 \%$ sehingga persentase kelahiran terhadap populasi rendah. Nilai natural increase ini perlu terus ditingkatkan dengan cara menekan kematian ternak, meningkatkan kelahiran, mempertahankan betina produktif dan menambah populasi indukan di Kecamatan Bayang Kabupaten Pesisir Selatan Provinsi Sumatera Barat.

\section{Net Replacement Rate (NRR)}

Nilai NRR ternak sapi potong di
Kecamatan Bayang Kabupaten Pesisir Selatan Provinsi Sumatera Barat tahun 2016 dapat dilihat pada Tabel 4.

Nilai NRR dihitung dari jumlah ketersediaan bibit: kebutuhan bibit (pengganti) x $100 \%$. Nilai NRR digunakan untuk mengetahui kebutuhan ternak pengganti sehingga populasi diwilayah tersebut tetap seimbang berdasarkan jumlah kelahiran pedet. Menurut Sumadi et al. (2001) nilai NRR $<100 \%$ maka kebutuhan ternak pengganti tidak terpenuhi, sebaliknya bila nilai NRR $>100 \%$ maka kebutuhan ternak pengganti terpenuhi. Pada Tabel 4 menunjukkan persentase NRR pada semua sapi potong adalah $1307,79 \%$ jenis kelamin jantan adalah dan $674,34 \%$ jenis kelamin betina, artinya ketersediaan sapi jantan untuk pengganti sebanyak 13,07 kali dari kebutuhan, pada sapi betina untuk pengganti sebanyak 6,74 kali 
Tabel 4. Net replacement rate (NRR) sapi potong di Kecamatan Bayang Kabupaten Pesisir Selatan tahun 2016

\begin{tabular}{|c|c|c|c|c|c|c|c|}
\hline \multirow{2}{*}{ No } & \multirow{2}{*}{ Peubah (variable) } & \multicolumn{5}{|c|}{ Bangsa (breed) } & \multirow{2}{*}{$\begin{array}{c}\text { Semua } \\
\text { bangsa } \\
\text { (all breed) }\end{array}$} \\
\hline & & Pesisir & Bali & SimPes & SimPO & $\mathrm{BX}$ & \\
\hline \multirow[t]{4}{*}{1} & Jantan (male) & & & & & & \\
\hline & $\begin{array}{l}\text { a. Kebutuhan penjantan } \\
\text { pengganti }(\%)\end{array}$ & 0,00 & 7,75 & 13,75 & 0,55 & 1,64 & 0,77 \\
\hline & b.Ketersediaan pejantan & 10,47 & 8,62 & 10,63 & 9,09 & 7,14 & 10,07 \\
\hline & Net replacement rate $(\%)$ & 0,00 & 111,23 & 77,31 & 1652,73 & 435,37 & 1307,79 \\
\hline \multirow[t]{4}{*}{2} & Betina & & & & & & \\
\hline & $\begin{array}{l}\text { a. Kebutuhan betina } \\
\text { pengganti }(\%)\end{array}$ & 1,82 & 1,25 & 0,48 & 1,50 & 0,86 & 1,13 \\
\hline & b. Ketersediaan betina & 8,00 & 12,93 & 4,83 & 6,06 & 0,00 & 7,62 \\
\hline & Net replacement rate $(\%)$ & 439,56 & 1034,40 & 1006,25 & 404,00 & 0,00 & 674,34 \\
\hline
\end{tabular}

dari kebutuhan, sehingga Kecamatan Bayang Kabupaten Pesisir Selatan Provinsi Sumatera Barat dapat dinyatakan kelebihan ternak sapi jantan dan sapi betina.

Hasil penelitian ini jauh lebih tinggi dibandingkan nilai net replacement rate Susanti et al. (2015) pada sapi jantan sebesar $143,26 \%$ dan sapi betina $220,15 \%$, nilai net replacement rate hasil penelitian Putra et al. (2015) pada sapi jantan sebesar $87,68 \%$ dan betina $121,03 \%$ dan nilai net replacement rate hasil penelitian Samberi et al. (2010) pada sapi jantan sebesar $234,28 \%$ dan betina $189,59 \%$. Hal ini terjadi karena peternak hanya memelihara ternak jantan untuk digunakan sebagai tabungan dan menutupi kebutuhan saat masa sekolah tiba ataupun akan dijual pada saat hari raya Idul Fitri dan Idul Adha dengan tujuan untuk mendapatkan harga jual yang lebih tinggi. Sehingga banyak ternak sapi jantan dipelihara sebelum Idul Fitri dan Idul Adha, sedangkan ternak sapi betina tidak dijual hanya dipelihara untuk mendapatkan keturunan dan dikembangbiakan.

\section{Dinamika Populasi Ternak Sapi Potong}

Dinamika populasi ternak sapi di Kecamatan Bayang Kabupaten Pesisir Selatan Provinsi Sumatera Barat dari tahun 2012 sampai tahun 2016 dapat dilihat Tabel 5.
Rataan dinamika populasi cenderung menurun dengan persentase $1,71 \%$ atau sebanyak 66 ekor per tahunnya. Hal ini disebabkan oleh tingginya persentase ternak yang keluar dibandingkan ternak yang masuk. Sehingga diperlukan pembatasan pengeluaran ternak sapi betina khususnya ternak sapi betina produktif dari daerah ini untuk menanggulangi kekurangan ternak. Berdasarkan persamaan garis regresi $\mathrm{Y}=3857,40-588(\mathrm{X})$ dari analisis time series data populasi ternak sapi potong tahun 2012 sampai tahun 2016, maka dapat diestimasi populasi ternak sapi potong di Kecamatan Bayang Kabupaten Pesisir Selatan Provinsi Sumatera Barat tahun 2017 sampai 2021 seperti pada Tabel 10 dengan estimasi koefisien teknisnya sama.

Pada Tabel 6 menunjukkan populasi ternak sapi potong di lokasi penelitian tahun 2017-2021 menunjukkan penurunan populasi dengan rataan sebanyak 783,92 ekor $(25,83$ \%). Dengan kata lain bahwa Kecamatan Bayang Kabupaten Pesisir Selatan Provinsi Sumatera Barat mengalami kekurangan ternak sapi potong sebanyak 784 ekor atau sebesar 26 $\%$ dari populasi per tahunnya. Hal ini dapat terjadi apabila koefisien pemeliharaan ternak sapi potong tidak berubah atau sama. Dengan meningkatkan populasi ternak sapi betina produktif pada daerah ini dapat menutupi 
Tabel 5. Dinamika populasi sapi potong di Kecamatan Bayang Kabupaten Pesisir Selatan tahun 2012 sampai 2016

\begin{tabular}{lccc}
\hline \multirow{2}{*}{ Tahun } & Populasi & \multicolumn{2}{c}{ Kenaikan } \\
\cline { 3 - 4 } & & Ekor & $\%$ \\
\hline 2012 & 3925,00 & 0,00 & 0,00 \\
2013 & 3917,00 & $-8,00$ & $-0,20$ \\
2014 & 3927,00 & 10,00 & 0,25 \\
2015 & 3857,00 & $-70,00$ & $-1,81$ \\
2016 & 3661,00 & $-196,00$ & $-5,35$ \\
Rata-rata & 3857,40 & $-66,00$ & $-1,71$ \\
\hline
\end{tabular}

Tabel 6. Estimasi populasi sapi potong di Kecamatan Bayang Kabupaten Pesisir Selatan tahun 2017 sampai 2021

\begin{tabular}{lccc}
\hline \multirow{2}{*}{ Tahun } & Populasi & \multicolumn{2}{c}{ Kenaikan } \\
\cline { 3 - 4 } & & Ekor & $\%$ \\
\hline 2017 & 2093,40 & $-1567,60$ & $-74,88$ \\
2018 & 1505,40 & $-588,00$ & $-39,05$ \\
2019 & 917,40 & $-588,00$ & $-64,09$ \\
2020 & 329,40 & $-588,00$ & $-178,51$ \\
2021 & $-258,60$ & $-588,00$ & 227,37 \\
Rata-rata & 917,40 & $-783,92$ & $-25,83$ \\
\hline
\end{tabular}

kekurangan ternak sapi potong di daerah ini di masa mendatang.

\section{KESIMPULAN}

Dari hasil penelitian yang telah dilakukan dapat disimpulkan Kecamatan Bayang Kabupaten Pesisir Selatan Provinsi Sumatera Barat dapat dijadikan sebagai kawasan sumber bibit sapi potong. Hal ini dapat dilihat dari semua kriteria yang diukur: komposisi ternak sapi potong di Kecamatan Bayang Kabupaten Pesisir Selatan terdiri dari sapi Pesisir $(50,15 \%)$, sapi SimPes $(25,80 \%)$, Bali $(17,06 \%)$, sapi $\operatorname{SimPO}(3,75 \%)$, dan Brahman Cross (2,18\%). Dimana persentase sapi potong yang keluar $(6,12 \%)$ lebih tinggi dibandingkan dengan persentase sapi potong yang masuk $(5,10 \%)$. Nilai natural increase (NI) ternak sapi potong di Kecamatan Bayang Kabupaten Pesisir Selatan sebesar 17,64\%, yang menunjukkan nilai NI di daerah ini tergolong sedang. Populasi ternak sapi potong di Kecamatan Bayang Kabupaten Pesisir Selatan kelebihan 1207,79\% ternak jantan sebesar dengan nilai NRR jantan sebesar $1307,79 \%$ dan kelebihan 574,34\% ternak betina dengan nilai NRR sebesar $674,34 \%$. Rataan nilai output ternak yang didapatkan $0,77 \%$ untuk ternak jantan afkir dan $1,13 \%$ ternak betina afkir. Serta rataan sisa replacement jantan $(9,30 \%)$ dan sisa replacement betina $(6,49 \%)$.

\section{DAFTAR PUSTAKA}

Affandhy, L., P. Situmorang., P. W. Prihandini., D. B. Wijono, dan A. Rasyid. 2003. Performans reproduksi dan pengelolaan sapi potong induk pada kondisi peternakan rakyat. Pros. Seminar Inovasi Teknologi Peternakan dan Veteriner. Bogor, 29-30 September 2003, Puslitbang Peternakan.

Estimasi Pembibitan Ternak Sapi ... (Afriani et al.) 
Blakely, J. dan D. H. Bade. 1991. Ilmu Peternakan. Edisi Ke Empat. Terjemahan Srigandono. Gajah Mada University Press, Yogyakarta.

Direktorat Jenderal Peternakan. 1998. Usaha Peternakan, Perencanaan, Analisis dan Pengolahan. Direktorat Jenderal Peternakan, Jakarta.

Djagra, I. B. dan I. B. Arka. 1994. Pembangunan Peternakan Sapi Bali di Propinsi Daerah Tingkat I Bali. Loka karya Pengembangan Peternakan Sapi di Kawasan Timur Indonesia, Mataram.

Hardjosubroto, W. 1990. Penentuan Plafon Ekspor Sapi Potong. DPPM, Universitas Gadjah Mada, Yogyakarta.

Hardjosubroto, W. 1992. Pola pembiakan dan output sapi potong di Daerah Istimewa Yogyakarta. Buletin Peternakan 16:54-62.

Hardjosubroto, W. 1994. Aplikasi Pemuliabiakan Ternak di Lapangan. PT. Gramedia, Jakarta.

Jan, R., I. P. Sudrana dan L. M. Kasip. 2015. Pengamatan Sifat-sifat yang Mempunyai Nilai Ekonomi Tinggi pada Sapi Bali di Kota Mataram. Fakultas Peternakan Universitas Mataram, Mataram.

Makanuwey, R. A. 2009. Struktur dan Dinamika Populasi Sapi Potong di Kecamatan Lore Peore Kabupaten Poso. Skripsi. Universitas Tadulako. Palu.

Murtiyeni, E. Juarini dan B. Wibowo. 2011. Profil dan Produktivitas Pembibitan Sapi Potong Sistem Komunal Pada Peternakan Rakyat di Kabupaten Kediri. Pusat Penelitian dan Pengembangan Peternakan, Bogor.

Nuryadi dan S. Wahjuningsih. 2011. Penampilan reporoduksi sapi Peranakan Ongole dan Peranakan Limousin di Kabupaten Malang. J. Ternak Tropiks 12(1) :76-81.

Putra, D. E., Sumadi, dan T. Hartatik. 2015. Estimasi Output Sapi Potong di
Kabupaten Pesisir Selatan Provinsi Sumatera Barat. Jurnal Peternakan Indonesia 17(2):105-115.

Rosikh, A., A. Aria, dan M. Qomarudin. 2015. Analisis Perbandingan Angka Calving Rate Sapi Potong Antara Kawin Alami Dengan Inseminasi Buatan di Kecamatan Dukun Kabupaten Gresik. Fakultas Peternakan Universitas Islam Lamongan, Lamongan.

Sulistia, I. 2007. Estimasi natural increase dan pola pemeliharaan sapi Bali di Kabupaten Penajam Paser Utara, Kalimantan Timur. Skripsi. Fakultas Peternakan Universitas Gadjah Mada, Yogyakarta.

Sumadi., N. Ngadiono, dan Soeparno. 1991. Penampilan Produksi Sapi Fries Holland, Sumba, Ongole, dan Brahman Cross yang Dipelihara Secara Feedlod. Fakultas Peternakan Universitas Jenderal Sudirman, Purwokerto. Hal: $116-126$.

Sumadi., W. Hardjosubroto., N. Ngadiyono, dan S. Prihadi. 2001. Potensi Sapi Potong di Kabupaten Sleman. Analisis dari Segi Pemuliaan dan Produksi Daging, Yogyakarta.

Susanti, A. E., N. Ngadiyono, dan Sumadi. 2015. Estimasi output sapi potong di Kabupaten Banyasin Provinsi Sumatera Selatan. Jurnal Peternakan Sriwijaya. 17-28.

Tanari, M., Y. Duma., Y. Rusiyantono, dan M. Mangun. 2011. Dinamika populasi sapi potong di Kecamatan Pamoa Utara Kabupaten Poso. J. Agrisains 12 (1):2429.

Toelihere, M. R. 1983. Tinjauan tentang Penyakit Reproduksi pada ternak ruminansia besar. Pusat Penelitian dan Pengembangan Peternakan Bogor, Bogor.

Tonbesi, T. T. 2008. Estimasi Potensi dan Kinerja Sapi Bali di Kabupaten Timor Tengah Utara, Propinsi Nusa Tenggara Timur. Tesis. Pascasarjana Universitas 
Vol. 21 (2): 130-142

Gadjah Mada, Yogyakarta. 